\title{
Immediate effect of lung expansion techniques in neurosurgery patients detected by electrical impedance tomography: a randomized crossover study
}

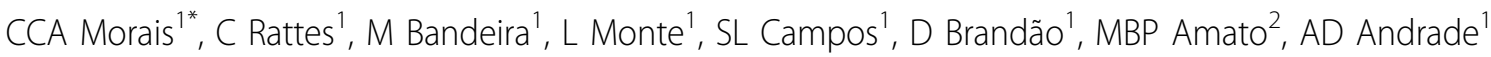 \\ From ESICM LIVES 2015 \\ Berlin, Germany. 3-7 October 2015
}

\section{Introduction}

The survival of patients with lesions in the central nervous system is usually accompanied by physical and mental sequelae. These impairments favor the prolonged restriction to the bed, which may contribute with changes in respiratory function. In this context, lung reexpansion techniques are used to prevent or treat the various respiratory complications.

\section{Objectives}

To compare the effect of Breath Stacking (BS) and Expiratory Positive Airway Pressure (EPAP) techniques on the regional lung ventilation, aeration and on the maintenance of the therapeutic effect of lung expansion in non-cooperative neurosurgery patients with prolonged bed rest. Secondary aims included to evaluate the influence of these techniques on cardiorespiratory system.

\section{Methods}

This was a randomized crossover study. Ten patients were included with Glasgow Coma Scale between 3-10 points, 18-65 years old, undergoing neurosurgery, unable to respond to the command and restricted to bed. The regional lung ventilation and aeration changes were assessed by EIT device (Enligh 1800, Timpel, São Paulo, Brazil). For interventions, EPAP was applied through a Spring Load valve resistor, adjusted with a pressure of $10 \mathrm{cmH} 2 \mathrm{O}$. BS was performed three times with one minute intervals

'Universidade Federal de Pernambuco, Physiotherapy, Recife, Brazil Full list of author information is available at the end of the article between them. The volume was stacked and maintained until 40 seconds.

\section{Results}

The regional lung ventilation during the BS was significantly higher in the inter-intervention and intra-intervention analyses when compared the baseline with the first minute (all $P<0.001$ ). The regional lung aeration was increased after both techniques significantly (all $P<0.001$ ), however, the BS increase more than EPAP $(P<0.001)$. There were no differences in the duration of therapeutic effect between the EPAP $(4.6 \pm 3.7$ minutes $)$ and BS ( $2.3 \pm$ 2.0 minutes $)(P=0.103)$ and there were no clinically significant differences on cardiorespiratory variables.

\section{Conclusions}

The BS and EPAP techniques promoted significant changes on lung volumes, but not maintained the therapeutic effect of lung expansion for a long time, and did not generate adverse effects on the cardiovascular system in non-cooperative neurosurgery patients with prolonged bed rest.

\section{Grant Acknowledgment}

This work was supported by grants from the Conselho Nacional de Desenvolvimento Científico e Tecnológico, Brazil (CNPq), and the Fundação de Amparo a Ciência e Tecnologia do Estado de Pernambuco (FACEPE).

\footnotetext{
Authors' details

'Universidade Federal de Pernambuco, Physiotherapy, Recife, Brazil.

${ }^{2}$ Universidade de São Paulo, Pulmonary Division, Sao Paulo, Brazil.
} 


\section{References}

1. Baker WL, Lamb VJ, Marini JJ: Breath-stacking increases the depth and duration of chest expansion by incentive spirometry. The American review of respiratory disease 1990, 141:343-346.

2. Costa EL, Lima RG, Amato MB: Electrical impedance tomography. Current Opinion in Critical Care 2009, 15(1):18-24.

3. Schans CP, De Jong W, De Vries G, Postma DS, Koeter GH, Van der Mark T, Van der: Effect of positive expiratory pressure on breathing pattern in healthy subjects. Eur Respir J 1993, 6:60-66.

doi:10.1186/2197-425X-3-S1-A991

Cite this article as: Morais et al:: Immediate effect of lung expansion techniques in neurosurgery patients detected by electrical impedance tomography: a randomized crossover study. Intensive Care Medicine Experimental 2015 3(Suppl 1):A991.

\section{Submit your manuscript to a SpringerOpen ${ }^{\mathcal{O}}$ journal and benefit from:}

- Convenient online submission

- Rigorous peer review

- Immediate publication on acceptance

- Open access: articles freely available online

- High visibility within the field

- Retaining the copyright to your article

Submit your next manuscript at $\gg$ springeropen.com 